\title{
Knowledge of the Poznan region citizens about speech therapy profession
}

\begin{abstract}
Agata Trębacz, Knowledge of the Poznan region citizens about speech therapy profession. Interdisciplinary Contexts of Special Pedagogy, no. 27, Poznań 2019. Pp. 197-221. Adam Mickiewicz University Press. ISSN 2300-391X. e-ISSN 2658-283X. DOI: https://doi.org/10.14746/ikps.2019.27.10

In recent years, the speech-language pathology has developed dynamically. It plays a growing role not only in the area of education but also in the field of medicine. Teaching correct articulation is just one of possible challenges faced by speechlanguage pathologists. The multidisciplinary context of that field of knowledge can be seen in various subfields of speech-language pathology which have evolved over time. Therefore, the primary objective of the conducted research was to assess the awareness of the importance of speech-language pathologists in everyday life of children and adults. The research was carried out among 50 respondents in the city of Poznan and provided the ground for discussion on the subject being the core issue of the presented paper.
\end{abstract}

KEY WORDS: speech therapist's competences, speech therapy, speech therapist

\section{Introduction}

In recent years, there has been a dynamic development of speech-language pathology (SLP) as a multi-, inter- and even transdisciplinary field of science, as its methodological basis presents a high level of intellectual reflection, which is supposed to create an 
immense space of new knowledge without strictly defined boundaries between sciences. As M. Michalik writes: "Speech-language pathology is becoming a science permeated by knowledge already formed, multi-disciplinary, [...] homogeneous, methodologically uniform". ${ }^{1}$ Not only speech-language pathologists, but also specialists in many other fields, including neurologists, audiologists, laryngologists, physiotherapists, dieticians, psychiatrists, sensory integration therapists and orthodontists, are involved in the diagnosis and therapy of patients revealing speech disorders, including pronunciation. Their knowledge allows for a holistic approach to each individual patient and a multidirectional diagnosis of the symptom and cause, resulting in a chance to plan not only fragmentary, but comprehensive and effective therapy.

Although in the legal sense, SLP does not have the status of an independent scientific discipline, on the Polish research ground its subject has been clearly specified, defining it as the biological conditions of language and linguistic behaviour. ${ }^{2}$ However, D. Pluta-Wojciechowska proposes to extend the scope of speech therapy research proposed by S. Grabias, indicating the procedures discussed by the author:

Speech-language pathology is the science of biological conditions of language and linguistic behaviours recognised in the course of symptom and cause diagnosis, used for programming and conducting therapy aimed at eliminating or reducing the intensity of disorders. ${ }^{3}$

The research subject defined in this way places SLP on the borderline between linguistics and medicine, but also (selectively) ped-

${ }^{1}$ M. Michalik, „Transdyscyplinarność logopedii - między metodologiczną koniecznością a teoretyczną utopią", [in:] Metodologia badań logopedycznych z perspektywy teorii i praktyki, eds. S. Milewski, K. Kaczorowska-Bray, Harmonia Universalis, Gdańsk 2015, pp. 32-43.

2 S. Grabias, „Teoria zaburzeń mowy. Perspektywy badań, typologie zaburzeń, procedury postępowania logopedycznego", [in:] Logopedia. Teoria zaburzeń mowy, eds. S. Grabias, J. Panasiuk, T. Woźniak, Wydawnictwo UMCS, Lublin 2014, pp. 32-39.

${ }^{3}$ D. Pluta-Wojciechowska, Efektywność terapii dyslalii. Logopedyczno-lingwistyczna analiza wyników badań, Wydawnictwo Uniwersytetu Śląskiego, Katowice 2019, p. 24. 
agogy and psychology, taking into account the fact that in their daily work, a speech-language pathologist uses elements of methods formulated on the basis of didactics, developmental psychology, clinical psychology or upbringing theory. But what lead to thinking of the originality of this branch of science? When analysing the place of speech-language pathology among other sciences, it should be noted that the repertoire of its diagnostic and therapeutic methods includes those that are specific, i.e. language programming, setting voice sequences, evoking normative realisation of phonetic features, etc. SLP not only draws on the achievements of these fields of science, but also contributes to building new knowledge through intensive and regular research on a variety of issues. Just as the brain collects, analyses, processes, interprets and integrates information from all the senses of the body, SLP collects, deepens and integrates knowledge of development and speech disorders from different scientific disciplines. ${ }^{4}$

In the social environment, however, it is not uncommon to encounter the creation of a one-dimensional image of a speechlanguage pathologist, recognizing that their primary role is to shape correct articulation, mainly in school-age children. ${ }^{5}$ Previous reports and comments from researchers, including D. Pluta-Wojciechowska and I. Michalak-Widera, also point to still prevalent myths about the profession of a speech-language pathologist, which on the one hand are not without influence on the sense of mission and self-esteem of speech-language pathologists, and on the other hand delay the start of proper SLP therapy, especially among young patients. The current myths can be summarised as follows:

4 D. Pluta-Wojciechowska, Efektywność terapii dyslalii. Logopedyczno-lingwistyczna analiza wyników badań, Wydawnictwo Uniwersytetu Śląskiego, Katowice 2019, pp. 22-35.

${ }^{5}$ According to own research conducted in the city of Poznan $(n=50)$, the primary school was the most frequently indicated place of employment of a speechlanguage pathologist. Only $11 \%$ of respondents indicated the possibility of employing a speech-language pathologist in medical facilities. Moreover, only $6 \%$ of the respondents answered that a speech-language pathologist is involved in the treatment of speech disorders and not only in the correction of speech defects. 
- a speech-language pathologist is a teacher of correct pronunciation,

- a speech-language pathologist is a person who works with children who are already talking,

- each child develops individually and starts talking when they are ready to do so,

- boys have more time to learn to talk than girls,

- a speech development delay is diagnosed when a child is 3 years old and does not speak or speaks very little. 6

Similarly, I. Michalak-Widera and J. Oczadły emphasise that instead of consciously supporting the development of a young child, the parent/guardian trusts the common belief that they may not speak at the age of 3 or that boys, like their fathers, start speaking later. ${ }^{7}$ It is possible this will be the case - the boys will start talking and make up for the deficits. But what if at the age of three their speech still has not developed? They will lose valuable time, and in an increasingly conscious child, frustration will grow due to the lack of verbal communication with the environment. Beginning therapy quickly gives the child a chance to achieve better results due to the high neuroplasticity of the brain and active neurogenesis in the early stages of development.

Although myths about the development of children's speech and the profession of the speech-language pathologist are still present in the social discourse, it should be noted that despite this, the profession of speech-language pathologist has developed significantly over the last years. Speech-language pathologists find employment in educational and medical institutions and promote reliable logopaedic knowledge, based on the results of scientific research (Evidence Based Practice) and individual experiences from their own workshop. Campaigns on social networking sites and

${ }^{6}$ D. Pluta-Wojciechowska, „Dokąd zmierza logopedia?”, Forum logopedyczne 2013, no. 21, p. 9.

7 I. Michalak-Widera, J. Oczadły, „Logopedyczne fakty i mity”, Forum logopedyczne 2013, no. 21, p. 22. 
other mass media, such as "Give me a chance to develop. Take away my smartphone" or "Stop the no-drip cups", which were the brainchild of speech-language pathologist Paulina Mistal, contribute to building parents' awareness of the correct habits that support the speech development of young children.

Speech-language pathologists work with children, adolescents and adults who have speech disorders in various forms, e. g. they manifest themselves in the form of articulation disorders, disorders of speech understanding or speech expressions. The diagnostic and therapeutic procedures they undertake take on a variety of character depending on the specific type of speech disorder presented by the patient. Such observations allow us to think about the multidimensional shape of speech-language pathology, which can be further proved by the multitude of sub-disciplines that have emerged on its ground: early speech-language pathology, speech-language neuropathology, SLP for the d/Deaf or hard of hearing, SLP for the blind/visually impaired, SLP for people with speech fluency problems, SLP for people with intellectual disabilities, clinical speech therapy, artistic/media speech therapy, SLP for the elderly and oncological SLP.

In theory and practice, early SLP intervention is understood as a speech therapeutic treatment of a child at risk of disability (e. g. a child born prematurely or with abnormal muscular tension) or with a diagnosed disability (e.g. a child with cerebral palsy or a child with a specific genetic defect), who is found to have an abnormal speech or primary function abnormalities, which are the foundation for proper speech development. Nevertheless, the literature postulates a broader perspective on early SLP intervention and defining its target audience not through the prism of their age, but through the need to take immediate action to early diagnosis of the disorder and to include appropriate therapeutic management. ${ }^{8}$ In the case of adults, the influence of the speech-language pathologist

${ }^{8}$ J.J. Błeszyński, „Wczesna interwencja - różne podejścia, ujęcia, definicje. Różne nie znaczy sprzeczne", [in:] Wczesna interwencja w logopedii, eds. J.J. Błeszyński, D. Baczała, Harmonia Universalis, Gdańsk 2015, p. 31-42. 
is aimed at counteracting the negative influence of the disorder at an early stage of its development on human communication and language competence, e. g. in Alzheimer's or Parkinson's disease.

Speech-language neuropathology focuses on the therapeutic effects on people who have suffered from disorders of linguistic communication as a result of damage to the central nervous system, especially the area of the frontal lobe, where the Broca's motor speech centre or the temporal lobe with Wernicke's sensory speech centre is located.

The area of interest of SLP for d/Deaf or hard of hearing people includes the issue of the influence of hearing impairment on the process of linguistic and communicative functioning of humans. A speech-language pathologist who undertakes the diagnosis and therapy of speech disorders in d/Deaf or hard of hearing people should have theoretical and practical preparation for this profession in all its dimensions, e. g. the ability to read the results of hearing tests, knowledge of objective and non-objective methods of hearing organ diagnosis, knowledge of the consequences of hearing disorders for speech and language development, the ability to introduce alternative and supportive communication methods, etc. ${ }^{9}$

SLP for the blind and visually impaired as one of the subdisciplines of specific speech therapy focuses on the diagnosis and therapy of language and communication skills of people with visual disabilities. The results of the conducted research indicate a specific course of speech development in children with visual impairment and provide data that shows that in the group of visually impaired and blind children, more often than in the group of sighted children, there are disorders in the development of the phoneticphonological system. ${ }^{10}$ Due to the lack of direct observation of articulatory patterns and the lack of visual stimulation to speak in the

${ }^{9}$ E. Muzyka-Furtak, Surdologopedia. Teoria i praktyka, Harmonia Universalis, Gdańsk 2015, pp. 13-14.

${ }_{10}$ M. Zaorska, „Tyflologopedia jako subdyscyplina szczegółowa logopedii oraz element jej współczesnej koncepcji strukturalnej", Przegląd Badań Edukacyjnych 2016, no. 22, pp. 149-162. 
early stages of speech development in a child with visual impairment, some delays are observed, especially with regard to the acquisition of concepts that are matched by specific visual images, such as spatial relationships. In working with blind/visually impaired patients, the speech-language pathologist places particular emphasis on a multimodal experience of the world in order to compensate for the shortcomings associated with visual disturbances.

In the case of SLP for people with speech fluency disorders, the subject of diagnostic and therapeutic effects are people with disorders of fluency of speech, including stuttering, tachylalia (pathological acceleration of speech rate) or bradylalia (pathological slowdown of speech rate). ${ }^{11}$ Finally, there are speech-language therapists who deal with the diagnosis and therapy of speech disorders in people with intellectual disabilities. ${ }^{12}$

Clinical speech-language pathology focuses on prophylactic, diagnostic and therapeutic treatment of people with neurological and genetic disorders, in psychiatric diseases or in dementia. The dictionary definition of the term "clinical" indicates that the abovementioned activities take place in a clinic. ${ }^{13} \mathrm{~A}$ clinical diagnosis can be made for any speech disorder and is not inseparable from the other areas identified.

The subject of diagnosis and therapy in artistic/media speech therapy is the correct technique of speaking, articulatory correctness and diction of voice professionals. The specialist in artistic/media speech therapy works with journalists, entertainers, actors or managers to improve the verbal and non-verbal elements of their public performances.

Gerontologic SLP explains the developmental conditions of changes in the quality of communication functions in people who are elderly, physiologically ageing, or with co-occurring neuro-

11 G. Gunia, „Strategie podwyższania jakości życia osób z zaburzeniami komunikacji”, Rocznik Komisji Nauk Pedagogicznychm 2017, Vol. LXX, p. 36.

${ }_{12}$ M. Kupisiewicz, Stownik Pedagogiki Specjalnej, Wydawnictwo Naukowego PWN, Warszawa 2013, p. 304.

13 Internetowy Słownik Języka Polskiego PWN [accessed: 21.08.2019]. 
degenerative disorders, e. g. in Parkinson's disease or Alzheimer's disease, ${ }^{14}$ and oncological SLP focuses on the diagnosis and SLP therapy of people who reveal primitive and secondary dysfunctions in the course of a cancer and/or as a result of its treatment. 15

Due to a small percentage of practising speech-language pathologists who treat people with psychogenic speech disorders (5-10\%), i.e. stuttering, schizophasia, selective mutism, as well as limited cooperation of speech-language pathologists with physiotherapists and an increasing percentage of bi- or multilingual children, Z. Tarkowski additionally postulates the creation of new SLP specialisations, namely: psychological SLP, physiological SLP and bilingual SLP, which would basically constitute a compilation of speech-language pathological, linguistic, psychological and medical knowledge, and would be conducted in the form of postgraduate education. 16

Looking at the list of the mentioned sub-disciplines in the field of speech therapy one may think that a speech-language pathologist can accompany an individual practically from the moment of their birth, when their task is, among others, to stimulate the sucking reflex, assess the readiness of a child born prematurely to take up food on their own, assess the structure of the oral-facial tract or the oral reflex reactions, ${ }^{17}$ until old age - when the primary role of a speech-language pathologist is seen in maintaining the communication skills of the elderly. ${ }^{18}$ A speech-language pathologist works with people (children, adolescents and adults) whose abnormalities

${ }^{14}$ K. Kaczorowska-Bray, „Gerontologopedia, czyli starość w perspektywie logopedycznej", Konteksty społeczne 2017, vol. 5, no. 1(9), p. 140.

15 A. Hamerlińska-Latecka, Onkologopedia - logopedia wobec chorób nowotworowych, Wydawnictwo Uniwersytetu Kazimierza Wielkiego w Bydgoszczy, Bydgoszcz 2015, p. 50.

16 Z. Tarkowski, „Nowe specjalizacje w logopedii”, [in:] Forum logopedy no. 14, Poznań 2016, pp. 59-61.

17 M. Czajkowska, „Współpraca fizjoterapeuty i specjalisty wczesnej interwencji logopedycznej w terapii niemowląt z grupy ryzyka", Forum Logopedyczne 2016, no. 24, pp. 159-163.

18 S. Milewski, K. Kaczorowska-Bray, B. Kamińska, „Późna dorosłość z perspektywy logopedii", Pogranicze. Studia społeczne 2016, Vol. XXVIII, p. 179. 
in verbal communication and building logical, grammatically correct statements are not infrequently an isolated disorder, but occur as a consequence of disorders in another area, e. g. neurological, genetic or anatomical. The listed disorders do not constitute a complete list of possible developmental abnormalities but are only an indication of potential causes of the need for intervention and SLP care by specialists of the previously discussed SLP sub-disciplines.

The range of diagnostic and therapeutic activities undertaken by speech-language pathologists depends mainly on the level of development of an individual and the degree of severity of deficits that inhibit or sometimes even prevent the process of learning verbal speech. Therefore, it seems reasonable to state that a speechlanguage pathologist, apart from shaping the correct articulation, deals with creating conditions for the proper development of speech, i.e. removing irregularities in primal activities ${ }^{19}$ and building a linguistic system in the mind of an individual to create space for their linguistic communication with the social environment. ${ }^{20}$ However, sometimes an individual is not able to verbally communicate with the people around them and then one of the tasks of a speech-language pathologist is to introduce supporting or alternative communication (pictograms, PECS, PCS, gestures, sign language, eye trackers and other devices) in order to enable them to participate in social life, to preserve subjectivity and to satisfy their individual emotional and social needs.

\section{Theoretical considerations on the concept of speech}

For the average language user, terms such as speech and language are identical in terms of meaning, but scientifically, there is a prima-

${ }^{19}$ D. Pluta-Wojciechowska, Zaburzenia czynności prymarnych i artykulacji. Podstawy postepowania logopedycznego, Wydawnictwo Ergo-Sum, Bytom 2015, pp. 18-19.

${ }^{20}$ J. Cieszyńska-Rożek, Metoda Krakowska wobec zaburzeń rozwoju dzieci. Z perspektywy fenomenologii, neurobiologii i językoznawstwa, Omega State Systems, Kraków 2013, p. 324. 
cy-subordination relationship between the two terms. The definition of speech presented in the Polish Language Dictionary emphasises the communicative aspect of the concept of speech and defines it classically as the uttering of words to communicate with other people. This simple definition contains the whole essence of the act of communication in question.

The currently proposed definition of speech in SLP literature is that of S. Grabias, who defines speech as "a set of activities that, a person performs with the participation of language while learning about reality and communicating its interpretation to other participants of social life" ${ }^{21}$ In such an approach, speech - as a subject of interest of the speech-language pathologist - appears to be a linguistic behaviour involving internal speech, i.e. a mental text organising the knowledge being passed on and external speech, which is a sound performance act of internal speech in the form of verbal communication. The proposed definition includes three specific types of activities fulfilling different functions:

a. cognitive activities - the person creates a mental picture of reality based on acquired knowledge, which is the result of understanding and active use of language,

b. linguistic communication activities - coexist with non-verbal expressive and gestural behaviour, and are a specialised tool for transmitting knowledge about oneself and reality to other members of society,

c. socialisation and group-forming activities - thanks to verbal acts, a person is subject to socialisation processes and learns the rules and principles of behaviour binding within specific social structures. ${ }^{22}$

The communicative competence of the participants in social life is determined by internalised "rules of suitability", which deter-

${ }^{21}$ S. Grabias, „Teoria zaburzeń mowy. Perspektywy badań, typologie zaburzeń, procedury postępowania logopedycznego", [in:] Logopedia. Teoria zaburzeń mowy, eds. S. Grabias, M. Kurowski, Wydawnictwo UMCS, Lublin 2014, p. 15.

${ }^{22}$ Ibid., pp. 16-17. 
mine how to create linguistic messages appropriate to the situations in which they are formulated. An individual learns these communication rules through participation in social life, and the grammatical rules, which are a component of language competence, are both acquired and innate. Communication and language skills are created through perceptive and realisational biological skills, including well-functioning physical, phonematic and prosodic hearing, as well as a properly functioning peripheral nervous system.

The last participating competence in the communication process is the cultural (cognitive) competence, which is knowledge of the surrounding reality and thus enables mutual communication. $\mathrm{S}$. Grabias stresses that an appropriate level of linguistic competence is an important condition for mastering communicative and cultural competence.

The reason for discussing the above-mentioned competences is the fact that there are three leading SLP procedures in speech disorders therapy, which at the same time indicate the tasks undertaken by speech therapists, namely:

a. competence building,

b. improving implementation; stabilising competences,

c. reconstruction of competences. ${ }^{23}$

It follows from the above that a speech-language pathologist does not only "fix" incorrect pronunciation, but is a person who teaches an individual to communicate linguistically with the world or helps to rebuild their communication and language system lost e. g. due to a stroke or other neurological disorders.

The linguistic behaviour created on the basis of competence and efficiency is pronunciation, i.e. auditory production of phonemes. ${ }^{24}$ The aim of the articulation diagnosis conducted by a speechlanguage pathologist is to assess the normativity of the realisation of particular phonemes, e. g. the realisation of $[\mathrm{r}]$ in the word brother.

${ }^{23}$ Ibid., p. 53.

${ }^{24}$ D. Pluta-Wojciechowska, Dyslalia obwodowa. Diagnoza $i$ terapia logopedyczna wybranych form zaburzeń, Wydawnictwo Ergo-Sum, Bytom 2017, p. 110. 
If a speech-language pathologist finds an incorrect realisation of a particular phoneme, their task is to identify the reason for such realisation. In the pronunciation evaluation D. Pluta-Wojciechowska postulates moving away from a diagnosis based on the auditory method (traditional method) to a multisensory diagnosis (strategic method), in which the speech-language pathologist must demonstrate knowledge of the phonetic-phonological system in order to make a precise description of non-standardised phonemes. This means that in the context of pronunciation, it is possible to speak about substance disturbances in the segmental plane, and in the case of speaking about content and language disturbances. ${ }^{25}$

\section{Tasks of a speech-language pathologist}

Articulation disorders may be caused by various abnormalities, both in functional (e.g. limited mobility of the tongue), anatomical (e.g. malocclusion) and functional-anatomical (e.g. shortened lingual frenulum) dimensions. Before starting the proper therapy of the disturbed phonemes, the speech-language pathologist should determine the cause of such a state of affairs and before calling out the phoneme, obtain the threshold conditions for learning selected sounds and selected phonetic features. This means that in diagnostic and therapeutic interactions the cause and effect criterion should be followed, and speech therapy procedures should be designed based on the acquired knowledge. For example: if the speechlanguage pathologist evaluates the sublingual frenulum and finds that its abnormal structure restricts the mobility of the tongue and thus causes abnormal articulation or insufficient cleaning of the oral cavity from residual food, then the child should be referred to a specialist, e. g. an ENT specialist or a paediatric surgeon, who will

${ }^{25}$ S. Grabias, „Teoria zaburzeń mowy. Perspektywy badań, typologie zaburzeń, procedury postępowania logopedycznego", [in:] Logopedia. Teoria zaburzeń mowy, eds. S. Grabias, M. Kurowski, Wydawnictwo UMCS, Lublin 2014, pp. 40-41. 
perform a frenotomy (i.e. the cutting of the sublingual frenulum). Removing the direct cause of faulty articulation is the foundation of effective therapy.

The causes of articulatory difficulties observed in a child may also be disorders at the level of biomechanical articulatory base (primitive functions), such as breathing, drinking and swallowing. In such cases, the speech-language pathologist first of all focuses on shaping the correct airway and the correct resting position of the tongue during physiological breathing, in which the tongue should be lifted from the bottom of the oral cavity and raised to the palate with the dorsal part, taking the vertical-horizontal position. ${ }^{26}$ The correct resting position also determines correct swallowing. Normally, in children over 3 years of age, it should proceed with a contraction of the mandibular-pharyngeal muscles lifting the bottom of the oral cavity and pressing the broad tongue posteriorly, with a short circuit (or slight opening of the teeth), closing of the lips and, what is important, with the lack of activity of the chin muscle. Unfortunately, it is increasingly common for children to perpetuate the so-called infantile swallowing mode, with the tongue being flattened and extended into the intergingival/ interdental space as a result of improper dietary expansion, shortening of the sublingual frenulum, improper eating habits, e. g. using a non-drip cup, bottles with a "spout" or educational habits, e. g. prolonged sucking of a soother or thumb and habitual oral breathing. ${ }^{27}$ In this case, the role of the speech therapist is also seen in building the parents' awareness of the choice of a safe feeding position (especially for newborns and infants) and the selection of appropriate accessories for drinking, eating and non-nutritive sucking (soother), emphasising that it should not be the brand or design that is important, but the right shape, size and type of material that will help to reduce the risk of malocclusion, as well as support the active work of the artic-

${ }^{26}$ D. Pluta-Wojciechowska, Dyslalia obwodowa. Diagnoza i terapia logopedyczna wybranych form zaburzeń, Wydawnictwo Ergo-Sum, Bytom 2017, p. 201.

27 D. Pluta-Wojciechowska, Zaburzenia czynności prymarnych i artykulacji. Podstawy postepowania logopedycznego, Wydawnictwo Ergo-Sum, Bytom 2015, pp. 74-84. 
ulatory apparatus and ensure the development of the correct position of the tongue during physiological breathing and swallowing. ${ }^{28}$

A speech-language pathologist employed at a school or kindergarten mainly focuses on shaping the correct articulation in order to prevent possible learning difficulties in reading and writing and to support the child's effective communication with the social environment. ${ }^{29}$ Moreover, they devote a lot of attention to the development of small motor skills, as it indirectly determines the proper functioning of articulatory apparatus (language, lips and jaws) due to the close location of centres responsible for the precise work of the hand and the motor skills of articulatory organs in the motor cortex. In their therapeutic work, the speech-language pathologist also works on shaping creative verbal activity by expanding passive and active lexical resources, improving the work of the visual and auditory analyser, developing grammatical, semantic and syntactic skills, as well as improving storytelling/narrative speech while maintaining the rules of logical thinking, which develops in children around the age of 4 , when they move away from the egocentricity of thinking and explaining the surrounding reality through the prism of their own experiences in favour of interpreting events from the perspective of other people. ${ }^{30}$

Articulation disorders may also be a consequence of abnormalities in the development of phonemic hearing (in other words: phonematic, phonological). The literature on the subject presents narrow and broad meanings of this term; however, according to B. Rocławski, who made a stage description of the development of

${ }^{28}$ E. Kaptur, J. Sławek, „Od karmienia do mówienia. Wpływ funkcji prymarnych na rozwój mowy”, [in:] Forum Logopedy no. 22, Poznań 2017, pp. 40-41.

29 The literature on the subject states that persistently incorrect phoneme realisations may contribute to difficulties in learning to read and write [cited in: A. Jopkiewicz, Konsekwencje społeczne, psychologiczne i pedagogiczne nieprawidłowego rozwoju mowy u dzieci, 2001, pp. 121-122).

30 S. Filipiak, „Ocena myślenia logicznego u dzieci w okresie średniego dzieciństwa na podstawie układania historyjek obrazkowych", Annales Universitatis Mariae Curie-Skłodowska Lublin-Polonia 2018, Vol. XXXI, 1, p. 120. 
phonemic hearing from birth until the child reaches full ability to identify voices, it is "the ability to qualify voices distinguished from the speech stream as belonging to specific, phonologically determined classes". ${ }^{31}$ It therefore enables the correct identification and understanding of words that differ by one distinctive feature, forming a phonological opposition. For example, there is a phonological opposition between the phonemes [p] and [b] - in the onset of the words pill - bill, based on the presence or absence of sonority, which suggests that sonority should be considered a distinctive feature differentiating the meaning of these words. The development of the perception of phonetic phenomena precedes verbal expression and ends before the child reaches the age of 1 , while the phonological system is gradual and should be fully developed by the age of 5-7. The intervention of a speech-language pathologist in the case of phonemic hearing disorders proves to be necessary, as any abnormalities in this respect may contribute to delays in speech development, difficulties in learning to read and write, as well as pronunciation defects in the form of deformations or soundless speech.

Shaping correct diction, improving the speaking technique, as well as controlling the fluency of speaking are another possible influence of speech-language pathologists. The above contents refer to the most common SLP problems and certainly do not discuss all potential areas of SLP support, as the therapy plan is always adapted to the individual needs of each person, and they can be very different and mutually determined. Early SLP prophylaxis in groups of nursery-age toddlers and the provision of specialised speech therapy care for children at the preschool stage give a chance to reduce the number of children suffering from primary, speech and articulation disorders at subsequent educational stages.

Due to the increasing proportion of children with special educational needs, including those with autism spectrum disorders, motor disabilities, including aphasia, intellectual, visual and auditory

31 B. Rocławski, Stuch fonetyczny i fonemowy. Teoria i praktyka, Wydawnictwo Uniwersytetu Gdańskiego, Gdańsk 1994, p. 20. 
disabilities, and the increasing number of opinions about the need for early support for the development ${ }^{32}$, speech-language pathologists not only act as teachers of correct articulation, but also undertake holistic therapy aimed at developing the communication behaviour of the individual. It is not uncommon to work on building eye contact, triggering communication intentions, shaping understanding of language messages and imitation, trying to pronounce the first words and combining the first sentences, or more generally, on shaping basic communication skills and reproducing the normative course of speech development. A speech-language pathologist gives people with speech disorders the tools to communicate, i.e. spoken language - if it is possible to develop verbal speech - or supporting and alternative communication, in order to compensate for the disorders and to pave the way for communication and language. However, it should be stressed that the introduction of supportive and alternative modes of communication does not preclude the simultaneous development of active speech, as shown by a number of studies conducted on a global scale. 33

In the case of people with neurological disorders, brain tumours, genetic defects, impairment of intellectual functions or prematurely born babies, with perinatal strains or cleft lips and/or palates, the need for a wider spectrum of SLP treatment is recognised not only in the context of developing communication skills, but also in the context of food intake, swallowing, improvement of articulatory

32 The conclusion is based on the analysis of statistical data concerning the number of students with special educational needs in individual voivodeships in the 2016/2017, 2017/2018 and 2018/2019 school years. The number of children covered by early development support in 2006-2018 is also worrying. In 2006, psychological-educational centres issued 16,015 opinions on the need for early development support, and in 2018, the number of opinions increased to 57,741, i.e. almost four times higher. Data available in the Educational Information System (access: 17.06.2019).

${ }^{33}$ A. Smyczek, "Zastosowanie wspomagających i alternatywnych metod komunikacji (AAC approach) $w$ terapii małych dzieci zagrożonych poważnymi zaburzeniami w porozumiewaniu się", [in:] Alternatywne i wspomagajace metody komunikacji, ed. J. Błeszyński, Oficyna Wydawnicza „Impuls”, Kraków 2017, p. 64. 
apparatus muscles with the use of intra- and extraoral massage techniques, flexible kinesiotaping of the orofacial sphere, stimulation of absent or extinguishing persistent oral reflexes of the oral-facial complex or undertaking food selectivity or neophobia therapy.

In the area of feeding therapy, speech-language pathologists focus mainly on the safe positioning of people with increased or decreased muscle tension for the duration of food intake, sensitising or de-sensitising the articulatory system, expanding the diet, learning about new foods and new consistencies, practising biting, chewing and mature swallowing. It is also important to select the right accessories for feeding and drinking in such a way that they are adapted to the individual structural and functional capabilities of the orofacial sphere - considering their shape, size and material. The feeding therapist pays attention to the way the bottle and spoon are administered, which should be positioned perpendicularly to the plane of the baby's face, forcing the protrusive movement of the mandible and thus preventing the mandibular retrogenia of the newborn from becoming permanent. In addition, they should teach parents the correct way of spoon feeding from the 4th month of age so that the lips actively participate in taking food off the spoon, preparing for articulation of the lip sounds, the normative realisation of which requires the involvement of the orbicularis oris muscle of the lower and upper lip. ${ }^{34}$

In the light of the above considerations, the speech-language pathologist should therefore appear in the eyes of society as a specialist with a range of tools and skills to support the development of primitive activities and speech, as well as to improve communication and language skills not only of children and adolescents, but also of adults. Speech-language pathologists are employed in neonatal and stroke wards, which shows the deep need to support patients regardless of their age. What is more, SLP has developed

${ }^{34}$ E. Gacka, „Zapobieganie nieprawidłowościom w rozwoju artykulacji u dzieci", Interdyscyplinarne konteksty pedagogiki specjalnej 2019, no. 21, p. 136. 
a number of methods for the diagnosis and therapy of speech disorders, which are the subject of extensive scientific studies, indicating both the leading methods of shaping and restoring communication and language competence and performance skills, as well as other supporting methods, such as Sensory Integration or movement, speech and music therapy. ${ }^{35}$ Many well-known authorities in the field of SLP, who are not only involved in scientific activities, but also conduct diagnosis and therapy of speech disorders in speech therapy clinics, want to share their knowledge, experience and workshop by organising training on various areas of SLP influence. A rich offer of trainings for speech-language pathologists, many new and systematically edited bibliographical items and a wide range of conducted scientific research allow us to claim that speech-language pathology undoubtedly constitutes a transdisciplinary field of knowledge which is developing dynamically every year and introduces a new order not only in the thinking of therapists but also in the thinking of doctors, educators, parents and guardians.

\section{Methodology and results of own studies}

In order to identify the state of knowledge about the profession of a speech-language pathologist, a quantitative survey was conducted among a randomly selected group of 50 residents of the city of Poznan between 20 and 60 years old. The research method used is a diagnostic survey and the selected technique is the interview. For the purpose of the study, an interview questionnaire was constructed, which addressed four key issues:

${ }^{35}$ Many strategies for the diagnosis and therapy of speech disorders have been developed in speech-language pathology, which are continuously verified and then described in scientific publications. One of the most recent publications presenting a list of SLP therapy methods is the extensive study Metody terapii logopedycznej, edited by A. Domagała and U. Mirecka (Wydawnictwo UMCS, Lublin 2018). 
1. The specifics of the speech-language pathology profession: Question 1: Who is a speech-language pathologist and what is the area of their diagnostic and therapeutic influence?

2. Gender in the profession of speech-language pathologist: Question 2: Who is a speech-language pathologist?

3. Target group of recipients of SLP aids:

Question 3: What is the target group of recipients of speechlanguage pathology aids? Who does the speech-language pathologist work with?

4. The place of employment of the speech-language pathologist: Question 4: Where can a speech-language pathologist find employment? Where does the speech-language pathologist work?

The motivation to undertake research on a specific subject was not only the reflections and observations of speech-language pathologists themselves that there are many myths about SLP in circulation in society, but also conversations with friends and families about the profession of a speech-language pathologist. In their statements, the author noticed some superficial statements and incomplete and sometimes false knowledge about the real competences of speech-language pathologists to work with children and adults. It has usually been suggested that a speech-language pathologist works with school-age children on "correct pronunciation of the sounds [sz] or [r]" and common opinions (myths!) about the development of a child's speech were repeated. More and more often it is said that SLP is such a multithreaded and dynamically developing area of knowledge that it is impossible to be a specialist in everything. This means that speech-language pathologists should specialise in working with a specific target group of patients in order to make the right diagnosis and organise effective therapy.

Two research questions were formulated, which were then answered using the collected interview data:

1. What is the social awareness of the residents of Poznan in the real area of diagnostic and therapeutic influences and the place of employment of the speech-language pathologist?

2. What is the social awareness of the residents of Poznan in terms of the age of people using SLP aids? 
The questions contained in the interview were open-ended, thus allowing full freedom of expression for the respondents and not suggesting any possible possibilities of response. The average age of male respondents $(n=20)$ was $\approx 37$ years, and for female respondents $(n=30) \approx 40$ years. The 50-person study group included women and men with both higher education and secondary or vocational education. The criteria for exclusion from the sample included the use of a language other than Polish as a mother tongue.

The first question was asked about who a speech-language pathologist is and what are the areas of their diagnostic and therapeutic interactions. The most frequent statements among the responses included statements that a speech-language pathologist deals with the therapy of pronunciation defects and the learning of correct articulation (90\%). However, the two answers above can be regarded as identical, as the work on correct articulation results from the presence of a specific type of pronunciation defect, e. g. incorrect realisation of voiced dentalised sounds. It should be noted that in total only $10 \%$ of the respondents indicated other possible actions taken by speech-language pathologists, i.e. speech disorders therapy $(6 \%)$, expanding the lexical resource $(2 \%)$ and learning the language system $(2 \%)$.

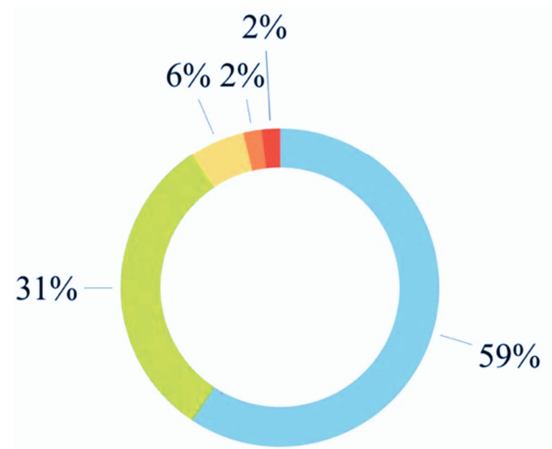

Teaching proper pronunciation

Correcting speech impediments

Speech disorder therapy

Teaching languages

Expanding vocabulary

Fig. 1. Percentage distribution of respondents' answers to the question: Who is a speech-language pathologist and what is the area of their diagnostic and therapeutic influence? 
On the basis of the collected data, it is therefore possible to assume a low awareness of the actual area of activities undertaken by speech-language pathologists and their competence to treat other disorders than just speech defects. None of the respondents indicated such areas as: visual and auditory gnosis exercises, feeding therapy, selection of eating and drinking accessories, narrative speech, introduction of supportive and alternative methods of communication, and many others described in the previous sections of this article.

The second question asked who can work as a speech-language pathologist. Almost half of the respondents, $42 \%$, stated that the profession of a speech-language pathologist is performed exclusively by women. When asked whether a man could take up a job as a speech-language pathologist, they replied that they had not encountered such a situation so far. Nearly $28 \%$ of the respondents stated that this profession is performed by both women and men, but with a strong emphasis on female dominance. Another $28 \%$ of people answered that a speech-language pathologist can be both male and female. The data collected confirms the beliefs about the feminisation of the speech-language pathologist profession, similar to other teaching positions. ${ }^{36}$

In the next question, the respondents were asked to indicate possible places of employment for speech-language pathologists. The vast majority of answers stated that a speech-language pathologist works in primary school $(88 \%)$ or kindergarten $(34 \%)$. Over $1 / 3$ of the respondents $(36 \%)$ stated that speech-language pathologists work in their own speech therapy practices, where they diagnose patients and organise individual speech therapy for them. 12 out of 50 respondents (24\%) answered that a speech-language pathologist may be employed in hospital wards, e. g. in a stroke or neurological ward.

Next, they were asked about potential recipients of a speechlanguage pathologist's care. The most frequently indicated group of recipients were school-age children $(82 \%)$, with particular emphasis

36 A. Gromkowska-Melosik, „Feminizacja zawodu nauczycielskiego - 'różowe kołnierzyki' i paradoksy rynku pracy", Studia Edukacyjne 2013, no. 25, pp. 85-100. 
on the period of early childhood education. Nearly half $(48 \%)$ of the respondents answered that speech-language pathologists organise therapeutic activities for pre-school children, and $30 \%$ of the respondents indicated that SLP support is also provided to adults after a stroke or those who have lost the ability to communicate effectively with the social environment as a result of communication accidents or brain/laryngeal cancer. One of all the people who took part in the interview indicated the area of artistic speech-language pathology, saying that speech-language pathologists can prepare candidates for theatre schools or to seek the correct technique for using the voice of journalists and politicians. It should be added that $6 \%$ of the respondents answered that only those children who already speak are covered by speech therapy, which in the light of the above mentioned considerations is an alarming signal as one of the tasks of a speech-language pathologist is to support linguistic development of non-speaking children.

Therefore, the collected data allow us to establish that among the residents of Poznan, there is a low awareness of other dimensions of SLP work beyond just the aspect of shaping the correct implementation of sounds, as well as the age of the target group of people using the support and knowledge of speech-language pathologists. Moreover, the results confirm the existence of previously discussed myths/stereotypes in the social consciousness about this professional group and testify to the incomplete knowledge of the respondents in the selected issue. The results obtained may indirectly signal low social awareness, when and to whom one should turn if a child does not develop communicativelanguage competence commensurate with age, or if an adult has growing problems in using speech in social contacts.

\section{Conclusions}

In the light of the presented considerations on the wide range of possible actions taken by speech and pronunciation disorders therapists, the opinions of respondents on the specificity of the speech- 
language pathologist profession, revealed by the results of the research, should be considered incomplete and superficial. The vast majority of the respondents, as many as $90 \%$, pointed to the formation of correct articulation, and only $6 \%$ to the therapy of sensu largo speech disorders. There is no doubt that a speech-language pathologist conducts the therapy of pronunciation defects; however, this is only one of many areas of their influence, looking at the multitude of sub-disciplines in modern speech-language pathology. Therefore, it is worrying that a large group of respondents $(>90 \%)$ do not have the appropriate knowledge to observe the development of children in a more conscious way, as well as to be a vigilant observer of adults who may also experience speech regression.

Speech-language pathologists have the right tools and competences to shape the linguistic and phonetic-phonological system of people of all ages. The specialisations identified in the field of speech therapy, e. g. early intervention, SLP for d/Deaf or hard of hearing people, or neurological SLP, thus testify to the need to provide therapeutic support not only to children/pupils who reveal articulation disorders, but especially to those whose speech disorders are secondary to other, superior developmental abnormalities or are one of the symptoms of a progressive disease process. Based on the collected research results, it can be assumed that there is a need in the social space for various information campaigns and meetings, free lectures and trainings on early symptoms of speech development disorders in children or first symptoms of language and communication skills limitations in adults.

\section{Bibliography}

[1] Cieszyńska-Rożek J., Metoda Krakowska wobec zaburzeń rozwoju dzieci. Z perspektywy fenomenologii, neurobiologii i językoznawstwa, Omega State Systems, Kraków 2013.

[2] Czajkowska A., „Współpraca fizjoterapeuty i specjalisty wczesnej interwencji logopedycznej w terapii niemowląt z grupy ryzyka", Forum Logopedyczne 2016, no. 24, pp. 159-163. 
[3] Filipiak S., „Ocena myślenia logicznego u dzieci w okresie średniego dzieciństwa na podstawie układania historyjek obrazkowych", [in:] Annales Universitatis Mariae Curie-Skłodowska Lublin-Polonia Vol. XXXI, 1, Lublin 2018.

[4] Gacka E., „Zapobieganie nieprawidłowościom w rozwoju artykulacji u dzieci”, Interdyscyplinarne konteksty pedagogiki specjalnej 2019, no. 21, p. 136.

[5] Grabias S., „Teoria zaburzeń mowy. Perspektywy badań, typologie zaburzeń, procedury postępowania logopedycznego", [in:] Logopedia. Teoria zaburzeń mowy, eds. S. Grabias, M. Kurowski, Wydawnictwo UMCS, Lublin 2014, pp. 32-39.

[6] Gromkowska-Melosik A., „Feminizacja zawodu nauczycielskiego - 'różowe kołnierzyki' i paradoksy rynku pracy", Studia Edukacyjne, 2013, no. 25, pp. 85-100.

[7] Gunia G., „Strategie podwyższania jakości życia osób z zaburzeniami komunikacji", Rocznik Komisji Nauk Pedagogicznych 2017, Vol. LXX, p. 36.

[8] Hamerlińska-Latecka A., Onkologopedia - logopedia wobec chorób nowotworowych, Wydawnictwo Uniwersytetu Kazimierza Wielkiego w Bydgoszczy, Bydgoszcz 2015.

[9] Kaczorowska-Bray K., „Gerontologopedia, czyli starość w perspektywie logopedycznej", Konteksty spoteczne 2017, vol. 5, no. 1(9), p. 140.

[10] Kaczorowska-Bray K., Milewski S., Wczesna interwencja logopedyczna, Harmonia Universalis, Gdańsk 2016.

[11] Kaptur E., Sławek J., „Od karmienia do mówienia. Wpływ funkcji prymarnych na rozwój mowy", Forum Logopedy 2017, no. 22, pp. 40-41.

[12] Kupisiewicz M., Stownik Pedagogiki Specjalnej, Wydawnictwo Naukowego PWN, Warsaw 2013.

[13] Michalak-Widera I., Oczadły J., „Logopedyczne fakty i mity”, Forum logopedyczne, 2013, no. 21, p. 22.

[14] Michalik M., „Transdyscyplinarność logopedii - między metodologiczną koniecznością a teoretyczną utopią", [in:] Metodologia badań logopedycznych z perspektywy teorii i praktyki, eds. S. Milewski, K. Kaczorowska-Bray, Harmonia Universalis, Gdańsk 2015, pp. 32-43.

[15] Milewski S., Kaczorowska-Bray K., Kamińska B., „Późna dorosłość z perspektywy logopedii", Pogranicze. Studia społeczne 2016, Vol. XXVIII, p. 179.

[16] Muzyka-Furtak E., Surdologopedia. Teoria i praktyka, Harmonia Universalis, Gdańsk 2015.

[17] Pluta-Wojciechowska D., Dyslalia obwodowa. Diagnoza $i$ terapia logopedyczna wybranych form zaburzen,, Wydawnictwo Ergo-Sum, Bytom 2017.

[18] Pluta-Wojciechowska D., Zaburzenia czynności prymarnych i artykulacji. Podstawy postępowania logopedycznego, Wydawnictwo Ergo-Sum, Bytom 2015.

[19] Pluta-Wojciechowska D., „Dokąd zmierza logopedia?”, [in:] Forum logopedyczne 2013, no. 21, p. 9.

[20] Pluta-Wojciechowska D., Efektywność terapii dyslalii. Logopedyczno-lingwistyczna analiza wyników badań, Wydawnictwo Uniwersytetu Śląskiego, Katowice 2019. 
[21] Rocławski B., Stuch fonetyczny i fonemowy. Teoria i praktyka, Wydawnictwo Uniwersytetu Gdańskiego, Gdańsk 1994.

[22] Smyczek A., "Zastosowanie wspomagających i alternatywnych metod komunikacji (AAC approach) $\mathrm{w}$ terapii małych dzieci zagrożonych poważnymi zaburzeniami w porozumiewaniu się", [in:] Alternatywne i wspomagajace metody komunikacji, ed. J. Błeszyński, Oficyna Wydawnicza „Impuls”, Kraków 2017, p. 64 .

[23] Tarkowski Z., „Nowe specjalizacje w logopedii”, Forum logopedy 2016, no. 14, pp. 59-61.

[24] Zaorska M., „Tyflologopedia jako subdyscyplina szczegółowa logopedii oraz element jej współczesnej koncepcji strukturalnej", Przegląd Badań Edukacyjnych 2016, no. 21, pp. 149-162. 